\title{
Antibacterial and antioxidant activities of Physalis peruviana and Hyphaene thebaica extracts
}

\author{
Sarah Mokhtar Abd-ELmageed*1, Hala Mohamed Abushady ${ }^{\mathbf{2}}$ and Afaf Ali Amin ${ }^{\mathbf{1}}$ \\ 1. National Nutrition Institute, Food Hygiene Department, Microbiology Unit, Egypt \\ 2. Ain Shams University, Microbiology Department, Science faculty, Egypt \\ *sarahmokhtar.505@gmail.com
}

\begin{abstract}
Ethanol extract of Physalis peruviana and water extract of Hyphaene thebaica were tested for their inhibitory effects on eight bacterial strains (Escherichia coli, Proteus mirabilis, Salmonella typhimurium, Salmonella entrica, Shigella dysenteriae, Bacillus cereus, Bacillus licheniformis and Staphylococcus aureus) by using well diffusion technique. The study demonstrated that Staph. aureus was the most sensitive gram-positive strain and $E$. coli was the most sensitive gram-negative strain to ethanol extract of Physalis peruvianae and water extract of Hyphaene thebaica. The inhibition zone diameters near to the synthetic antibiotic (ciprofloxacin). The antioxidant activity of the both extracts was also investigated by using 2, 2 - diphenyl, 1- picrylhydrazyl (DPPH) scavenging activity and ascorbic acid as control. The results showed that the scavenging effects of both extracts on DPPH radicals increased by increasing the concentration. The ethanolic extract of Physalis peruvianae and water extract of Hyphaene thebaica were a promising source of natural antimicrobial agent, antioxidant agent and as natural preservative of processed food.
\end{abstract}

Key word: Physalis peruvianae, Hyphaene thebaica, Antimicrobial activity, DPPH radical scavenging.

\section{INTRODUCTION}

Treatment with synthetic antibiotics is not always possible due to their high cost, development of widespread antibiotic resistance among the pathogens and undesirable side effects associated with the continued use of synthetic drugs (Kaur et al., 2010). Many people prefer to use preparations obtained from plants growing in their countries following folk tradition for alternative medication (Fabiola et al., 2002). Plant products may be used as antibiotic alternatives and do not cause resistance in bacteria (Arben $e t$ al., 2018).

The medicinal values of these plants lie in their polyphenolic components which produce definite physiological actions on the human body. The most important of these components are alkaloids, tannins, flavonoid and phenolic acids (Shariff, 2001).
Physalis peruviana belongs to the family Solanaceae and genus Physalis (Cedeño and Montenegro, 2004). It is a climacteric fruit grown in countries such as Peru, Venezuela, Egypt, South Africa, and Australia (Narváez Cuenca et al., 2014). It has been shown to provide significant health benefits because of its therapeutic properties such as anti-pyretic, antiinflammatory, anti-allergic, anti-ulcer, antimicrobial and anti-oxidant said (Tammu and Ramana, 2015). It was reported that the ethanolic extract of its fruit had antibacterial and antioxidant properties and it is used for treating diseases like cancer, leukemia, malaria, asthma, hepatitis, dermatitis and rheumatism Sathyadevi and Subramanian (2015)

Hyphaene thebaica is a desert palm native to Egypt, Sub-Saharan Africa and West India. It is called African doum (Dosumu et al., 2006). It belongs to the 
Sarah Mokhtar Abd-ELmageed et al.

family Arecaceae (Idrees and Mohammed, 2015). Various extracts of $H$. thebaica are being used in the treatment of bilharzia, haematuria, after child birth bleeding, and also as a haematinic agent (Adaya et al., 1977). The antimicrobial and antioxidant activities are shown greatly in the aqueous extract of the Doum fruit because of its luxurious amounts of water soluble phenolic contents (Hassan et al., 2018).

\section{MATERIALS AND METHODS}

\section{I- Materials:}

\section{1-Media and chemical reagents}

- Nutrient agar (Oxoid) (Lapage et al., 1970).

- Nutrient broth (Oxoid) (Bolton et al., 1984).

- Peptone water (Himedia): It used for bacteriological analysis.

- Ethyl alcohol 70\% (El-Nasr Pharmaceutical Chemical Company)

- Ciprofloxacin discs: as antibiotic

- 0.5 McFarland standard (Biomerieux)

- Ascorbic acid, and 2, 2-diphenyl1-picrylhydrazyl (DPPH)

\section{2-Plant materials}

Fresh ripened fruits of Physalis peruvianae (golden berry) and Hyphaene thebaica (Doum) were purchased in March 2015 from local markets in Egypt. The investigations were performed at Food Safety Department, Microbiology Unit in National Nutrition Institute, Cairo, Egypt.

\section{3- Identified bacterial strains}

Staphylo coccus aureusATCC

29213, Salmonella typhimorium ATCC 14028, Proteus mirabilis ATCC 43071, E. coli ATCC 10536, Bacillus licheniformis ATCC 14580, Bacillus cereus ATCC 10876 were obtained from TCS bioscience LTD, Botolph Clydon, Buckingham, MK 18 2LR, England. Salmonella entrica (Subspp. entricasero var Tennyson) and Shigella dysenteriae (Sub group A) proved by
Hygiene Institute/National Salmonella Center, (Federal German Republic). All strains were stored in nutrient agar stabs, sealed and kept in refrigerator and subcultured every three months.

\section{II-Methods}

\section{1-Preparation of different extracts:}

According to Jaca and Kambizi (2011) with slight modifications, for Physalis peruviana, the husks were carefully removed from the fruit by hand. Then the fruit samples were washed with tap water then by distilled water and gently wiped with paper tissue. Then they were air dried without direct exposure to the sun to avoid evaporation of some active compounds and ground into powder using a laboratory blender. Ten grams of golden berry powder were added in a flask with $100 \mathrm{ml}$ of ethanol $70 \%$ to obtain ethanolic extract of $P$. peruviana. Then this extract incubated at room temperature for 24 hours. The extract was filtrated by (Whatman no.1) and then the filtrate was concentrated at $40^{\circ} \mathrm{C}$ using oven till getting ride off solvent and having solid residue, which stored in freezer at $-20^{\circ} \mathrm{C}$ till use and rehydrated by water for further uses.

According to Aamer (2016) with slight modifications, fruits of Doum were washed by tap water then by distilled water and then were drained. The external part and the edible portion were crushed after scraping from the seed using stainless steel knife. The crushed portions were air dried, and then they were oven dried at about $45^{\circ} \mathrm{C}$ for three days. The dried portions were milled using electrical blender to obtain fine powder. Ten grams of Doum powder were added in a flask with $100 \mathrm{ml}$ of water to obtain water extract of Hyphaene thebaica. Then incubated at room temperature for 24 hours, The extract was filtrated by (Whatman no.1) and then the filtrates were concentrated at $40^{\circ} \mathrm{C}$ using oven till getting ride off solvent and having solid residue, which stored in freezer at $-20^{\circ} \mathrm{C}$ till use and rehydrated by water for further uses. 


\section{Antibacterial and antioxidant activities of Physalis peruviana and Hyphaene thebaica extracts}

\section{2-Preparation and standardization of inoculum:}

The tested bacteria were inoculated on nutrient broth and incubated at $37^{\circ} \mathrm{C}$ for 24 hours. The turbidity was adjusted to 0.5 McFarland turbidity standard (Doughari and Manzara, 2008).

\section{3-Preparation of extract concentrations:}

One gram of each extract put in 10 $\mathrm{ml}$ sterile distilled water and shaked well until dissolved under aseptic condition to prepare $10 \%$ concentration. The previous steps repeated by 3 and $5 \mathrm{~g}$. of each extract in $10 \mathrm{ml}$ sterile distilled water to make concentrations (30\%) and (50\%), respectively .

\section{4-Screening of antibacterial activity a-Well diffusion technique}

To observe the inhibitory spectrum of golden berry (Physalis peruviana) and Doum fruit (Hyphaen ethebaica) extracts against eight pathogenic bacteria. The screening of antibacterial activity was assessed based on the diameter of the clear zone surrounding the well (including the well diameter) in millimeter $(\mathrm{mm})$. The tests were conducted in triplicates (Aboaba et al., 2006) and (Nurmahani et al., 2012).

\section{b- Determination of Minimum Inhibitory Concentration (MIC) and Minimum Bacterial Concentration} (MBC) for each extract:

The lowest concentration that did not permit any visible growth was considered as MIC. MBC was considered as the lowest concentration that could not produce any growth (Aboaba et al., 2006).

\section{5-Determination of antioxidant activity:}

The antioxidant activity of plant material was assayed by DPPH assay. Freshly prepared $(0.004 \%$ w/v $)$ methanol solution of 2,2-diphenyl-1-picrylhydrazyl (DPPH) radical was prepared and stored at $10 \mathrm{C}^{\circ}$ in the dark. A methanol solution of the tested extracts was prepared. A $40 \mu \mathrm{L}$ aliquot of the methanol solution was added to $3 \mathrm{ml}$ of DPPH solution. Absorbance measurements were recorded immediately with a UV-visible spectrophotometer (Yen and Duh, 1994).The absorbance of the DPPH radical without antioxidant as control and the reference compound ascorbic acid were also measured. All the determinations were performed in three replicates.

The percentage inhibition (PI) of the DPPH radical was calculated according to the formula: (Yen and Duh, 1994)

$\mathrm{PI}=[\{(A C-A T) / A C\} \times 100]$

Where , $A C=$ Absorbance of the control at $\mathrm{t}=0 \mathrm{~min}$

$A T=$ Absorbance of the sample + $\mathrm{DPPH}$ at $\mathrm{t}=16 \mathrm{~min}$

\section{6-The statistical analysis}

Arithmetric mean $\pm \mathrm{SD}$, average and standard deviation were calculated using SPSS Statistical Package version 21 and the results were tabulated by Harvard graphics packages version 4 (1998), for representing the results graphically. A significant $P$-value was considered when $P$ is less than 0.05 (Jayawardana et al., 2015).

\section{RESULTS}

Table (1) and Figure (1) showed that the most sensitive microorganism for ethanol (70\%) extract of Physalis peruvianae was Escherichia coli with the highest mean value (19.0) followed by Staphylococcus aureus with mean value (17.67). Also, there was high significant difference between 10, 30 and $50 \%$ concentrations with $P$-value (0.008). 
Sarah Mokhtar Abd-ELmageed et al.

Table (1): Antibacterial activities of ethanol (70\%) extract of Physalis peruvianae expressed as inhibition zone diameter $(\mathrm{mm})$ at different concentrations $(10$, 30 and $50 \%$ )

\begin{tabular}{|l|c|c|c|c|}
\hline \multirow{2}{*}{ Bacterial species } & \multicolumn{3}{|c|}{ Conc. of Ethanol (70\%) extract } & Mean \pm SD \\
\cline { 2 - 5 } & $10 \%$ & $30 \%$ & $50 \%$ & \\
\hline Escherichia coli & 12 & 18 & 27 & $19.0 \pm 7.6$ \\
\hline Proteus mirabilis & - & 8 & 12 & $6.67 \pm 6.1$ \\
\hline Salmonella typhimurium & 10 & 12 & 16 & $12.67 \pm 3.1$ \\
\hline Salmonella entrica & - & - & 9 & $3.00 \pm 5.2$ \\
\hline Shigella dysenteriae & 11 & 14 & 18 & $14.3 \pm 3.5$ \\
\hline Bacillus cereus & 13 & 15 & 20 & $16.0 \pm 3.6$ \\
\hline Bacillus licheniformis & 10 & 12 & 17 & $13.0 \pm 3.6$ \\
\hline Staphylococcus aureus & 13 & 17 & 23 & $17.67 \pm 5.03$ \\
\hline Mean \pm SD & $8.63 \pm 5.44$ & $12.0 \pm 5.8$ & $17.75 \pm 5$. & $12.79 \pm 6.64$ \\
& \multicolumn{5}{|c|}{$0.008 * *$} \\
\hline -value & P & 7 & \\
\hline
\end{tabular}

$* P<0.05$ (Significant), $* * P \prec 0.01$ (Highly significant), (-) no inhibition

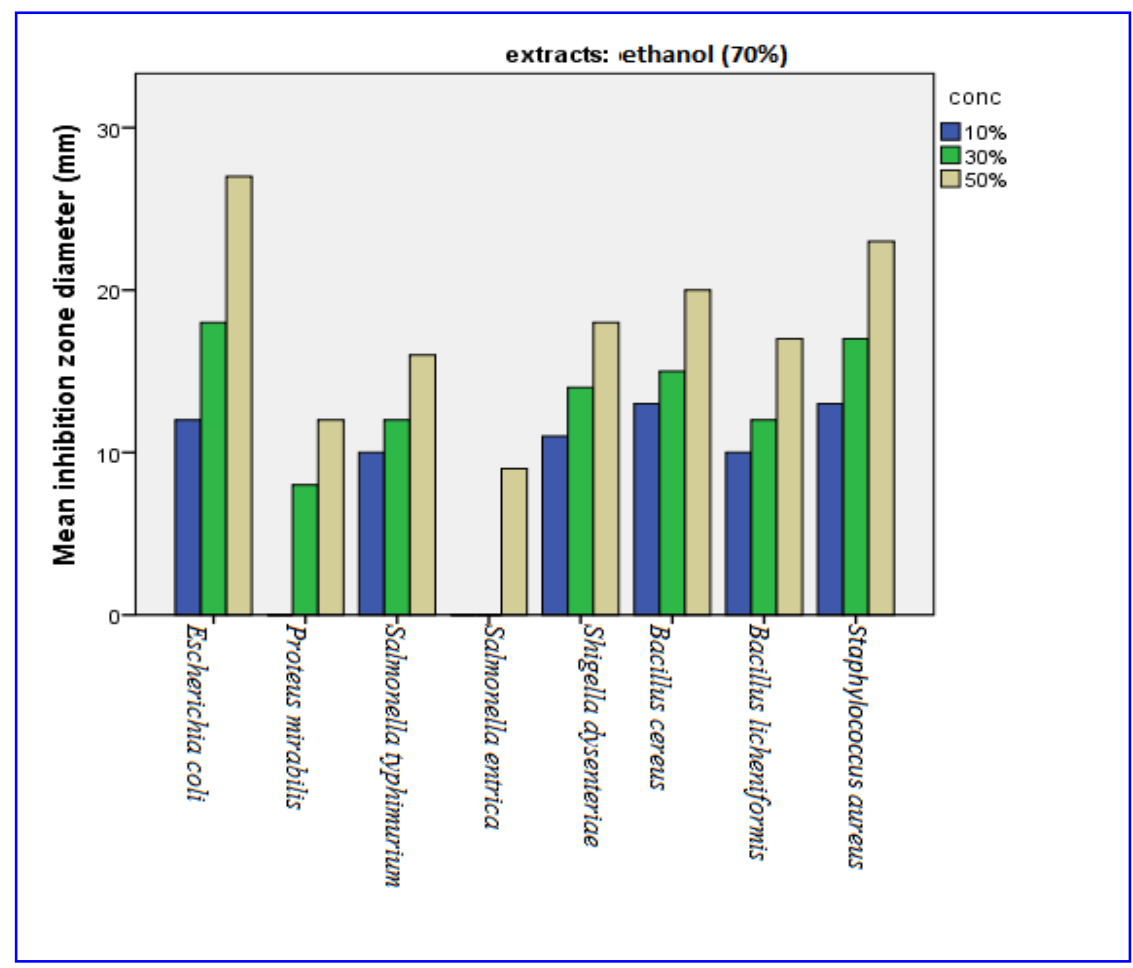

\section{Bacterial species}

Fig. (1). Mean inhibition zone diameter of each bacterial species at three concentrations $(10,30,50 \%)$ for ethanolic extract of Physalis peruvianae

Table (2) and Figure (2) for the water extract of Hyphaene thebaica showed that the most sensitive microorganism for was Staphylococcus aureus with the highest mean value (20.33) followed by Escherichia coli with mean value (16.00) also there was high 
significant difference between 10,30 and

$50 \%$ concentrations with $P$-value (0.009) .

Table (2): Antibacterial activities of Water extract of Hyphaene thebaica expressed as inhibition zone diameter $(\mathrm{mm})$ at different concentrations (10,30 and 50\%).

\begin{tabular}{|c|c|c|c|c|}
\hline \multirow[t]{2}{*}{ Bacterial species } & \multicolumn{3}{|c|}{ Water extract conc. } & \multirow[t]{2}{*}{ Mean $\pm S D$} \\
\hline & $10 \%$ & $30 \%$ & $50 \%$ & \\
\hline Escherichia coli & 12 & 16 & 20 & $16.00 \pm 4.0$ \\
\hline Proteus mirabilis & - & 7 & 10 & $5.67 \pm 5.13$ \\
\hline Salmonella typhimurium & - & 10 & 17 & $9.00 \pm 8.54$ \\
\hline Salmonella entrica & - & 6 & 10 & $5.33 \pm 5.03$ \\
\hline Shigella dysenteriae & - & 10 & 15 & $8.33 \pm 7.64$ \\
\hline Bacillus cereus & 12 & 15 & 17 & $14.67 \pm 2.52$ \\
\hline Bacillus licheniformis & 10 & 12 & 15 & $12.33 \pm 2.51$ \\
\hline Staphylococcus aureus & 17 & 20 & 24 & $20.33 \pm 3.51$ \\
\hline Mean $\pm S D$ & $6.38 \pm 7.09$ & $12.00 \pm 4.75$ & $16.0 \pm 4.72$ & $11.46 \pm 6.72$ \\
\hline P-value & & 0.0 & $09 * *$ & \\
\hline
\end{tabular}

$* P \ll 0.05$ (Significant), ${ }^{*} * \ll<0.01$ (Highly significant), (-) no inhibition

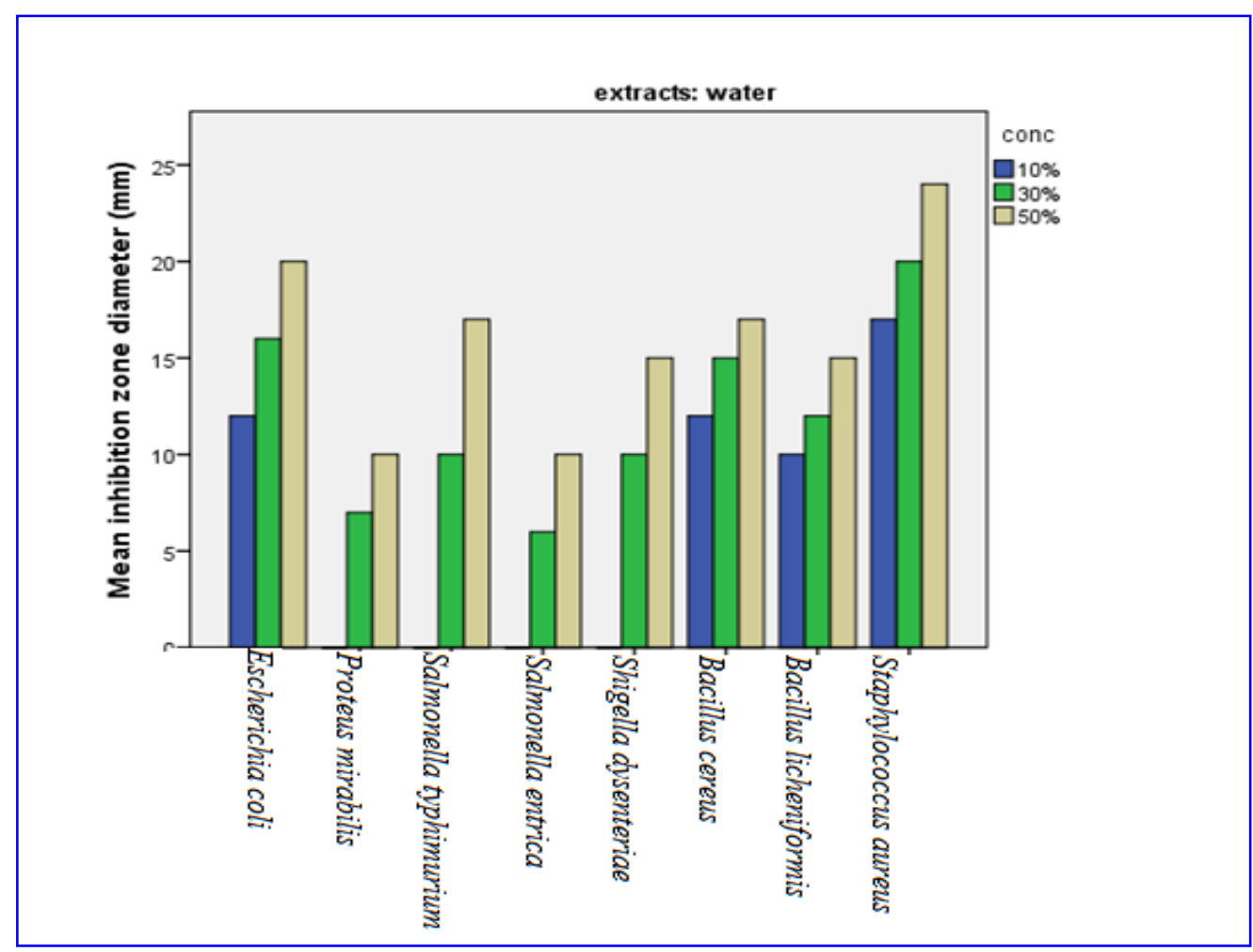

Bacterial species

Fig. (2). Mean inhibition zone diameter of each bacterial species at three concentrations $(10,30,50 \%)$ for Water extract ofHyphaen ethebaica.

Table (3) and Figures (3 \& 4) showed that antibacterial activity of natural extract of $P$. peruvianae was better than synthetic antibiotic for Staphylococcus aureus, and it has the same effect for Escherichia coli. Also, natural 
Sarah Mokhtar Abd-ELmageed et al.

extract of Hyphaene thebaica was better than synthetic antibiotic for
Staphylococcus aureus, and it has nearly the same effect for Escherichia coli.

Table (3): Comparison of antibacterial activities as inhibition zone diameter ( $\mathrm{mm})$ of natural extracts (at $50 \%$ concentration) versus standard synthetic antibiotic (Ciprofloxacin)

\begin{tabular}{|l|c|c|c|}
\hline \multirow{2}{*}{ Bacterial strains } & \multicolumn{2}{|c|}{ Natural extracts } & \multirow{2}{*}{ Ciprofloxacin } \\
\cline { 2 - 3 } & $\begin{array}{c}\text { Ethanolic extract of } \\
\text { physalis peruvianae }\end{array}$ & $\begin{array}{l}\text { Water extract of } \\
\text { Hyphaene thebaica }\end{array}$ & \\
\hline Escherichia coli & 27 & 20 & 27 \\
\hline Proteus mirabilis & 12 & 10 & 27 \\
\hline Salmonella typhimurium & 18 & 18 & 30 \\
\hline Salmonella entrica & 9 & 10 & 31 \\
\hline Shigella dysenteriae & 18 & 15 & 29 \\
\hline Bacillus cereus & 20 & 17 & 25 \\
\hline Bacillus licheniformis & 17 & 15 & 21 \\
\hline Staphylococcus aureus & 23 & 24 & $26.9 \pm 3.22$ \\
\hline Mean \pm S.D & $16.12 \pm 4.7$ & $18.63 \pm 5.2$ & \\
\hline p-value & 0.00 & 0.002 & \\
\hline
\end{tabular}

$* P<0.05$ (Significant), $* * P \ll 0.01$ (Highly significant), (-) no inhibition

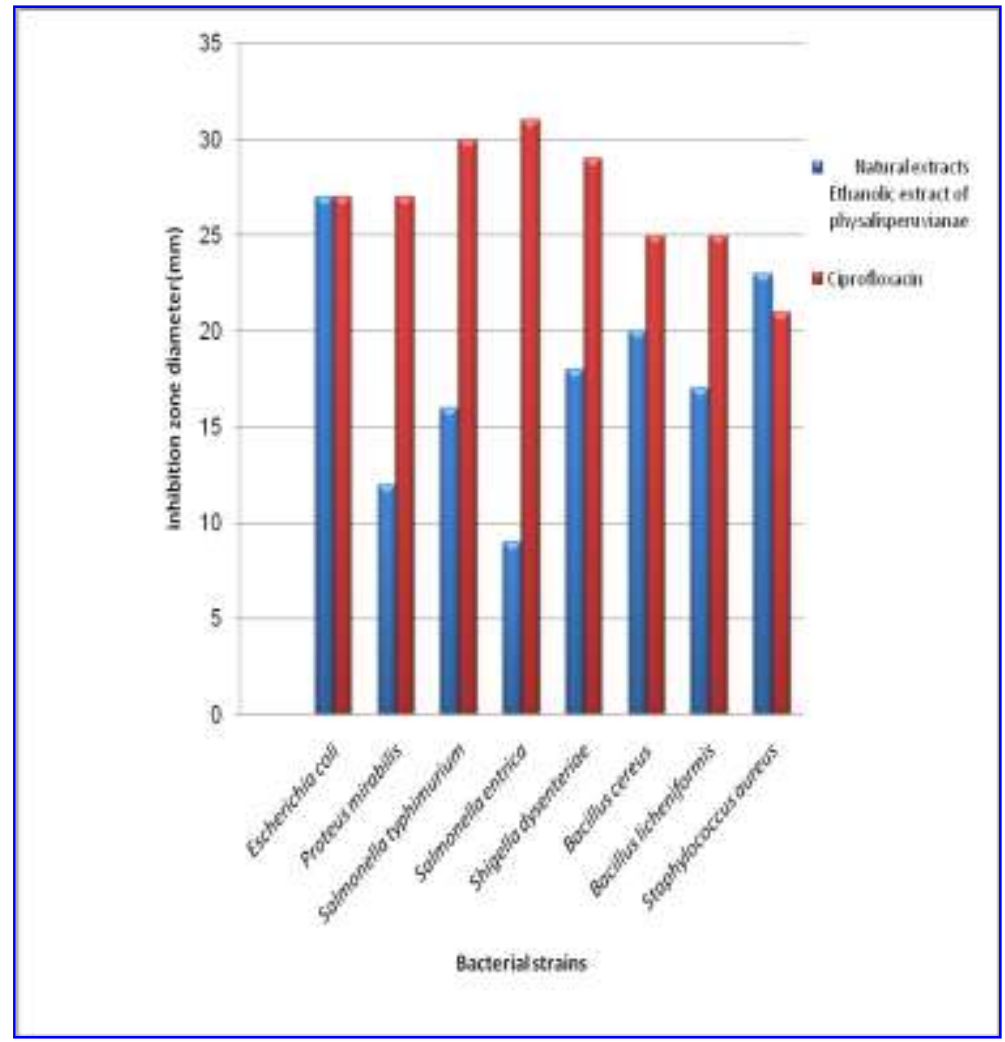

Fig. (3). Mean inhibition zone diameter of each bacterial species at ethanolic extract of Physalis peruvianae and ciprofloxacin. 
Antibacterial and antioxidant activities of Physalis peruviana and Hyphaene thebaica extracts

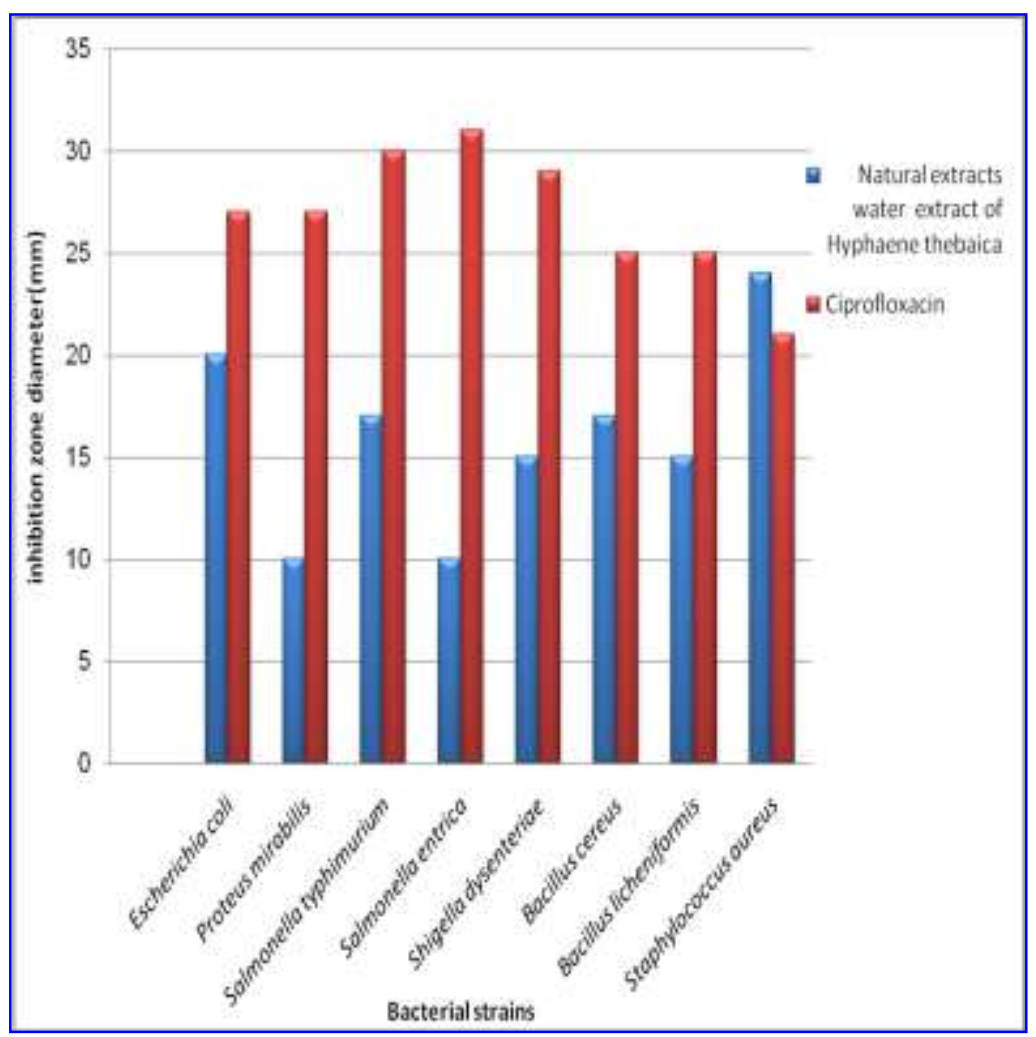

Fig. (4). Mean inhibition zone diameter of each bacterial species at water extract of Hyphaene thebaica and ciprofloxacin

Table (4). Bacteriostatic and bacteriocidal activities expressed as MICs and MBCs of Ethanol extact of Physalis peruvianae.

\begin{tabular}{|l|c|c|c|}
\hline \multicolumn{1}{|c|}{ Bacterial Species } & MIC & MBC & $\begin{array}{c}\text { Ratio } \\
\text { MBC/MIC }\end{array}$ \\
\hline E.coli & 12.5 & 12.5 & $=1$ \\
\hline Proteus mirabilis & 12.5 & 25 & $>1$ \\
\hline Salmonella typhimurium & 25 & 50 & $>1$ \\
\hline Salmonella entrica & 12.5 & 25 & $>1$ \\
\hline Shigella dysenteriae & 12.5 & 25 & $>1$ \\
\hline Bacillus cereus & 12.5 & 12.5 & $=1$ \\
\hline Bacillus licheniformis & 12.5 & 25 & $>1$ \\
\hline Staphylococcus aureus & 12.5 & 6.5 & $<1$ \\
\hline
\end{tabular}

MIC : Minimal inhibitory concentration (mg/ml extract)

MBC : Minimal bactericidal concentration ( $\mathrm{mg} / \mathrm{ml}$ extract)

If $\mathrm{MBC} / \mathrm{MIC}<$ or $=1$ (bacteriocidal )

If $\mathrm{MBC} / \mathrm{MIC}>1$ (bacteriostatic) 
Sarah Mokhtar Abd-ELmageed et al.

Table (5). Bacteriostatic and bacteriocidal activities expressed as MICs and MBCs of water extact of Hyphaene thebaica.

\begin{tabular}{|l|c|c|c|}
\hline Bacterial Species & MIC & MBC & Ratio MBC/MIC \\
\hline E.coli & 25 & 25 & $=1$ \\
\hline Proteus mirabilis & 25 & 50 & $>1$ \\
\hline Salmonella typhimurium & 25 & 25 & $=1$ \\
\hline Salmonella entrica & 6.5 & 12.5 & $>1$ \\
\hline Shigelladysenteriae & 6.5 & 12.5 & $>1$ \\
\hline Bacillus cereus & 6.5 & 25 & $>1$ \\
\hline Bacillus licheniformis & 12.5 & 25 & $>1$ \\
\hline Staphylococcus aureus & 6.5 & 6.5 & $=1$ \\
\hline
\end{tabular}

MIC : Minimal inhibitory concentration ( $\mathrm{mg} / \mathrm{ml}$ extract)

MBC : Minimal bactericidal concentration ( $\mathrm{mg} / \mathrm{ml}$ extract)

If $\mathrm{MBC} / \mathrm{MIC}<$ or $=1$ (bacteriocidal )

If $\mathrm{MBC} / \mathrm{MIC}>1$ (bacteriostatic)

\section{Antioxidant activity}

Table (6) and Figure (5) showed that DPPH scavenging activity of Ascorbic acid (natural antioxidant) which used as reference standard (control) increased with concentration, IC50 $=14.2 \mu \mathrm{g} / \mathrm{ml}$ (IC50: The half maximal inhibitory concentration).

Table (6). DPPH scavenging activity of different concentrations of Ascorbic acid as a reference standard.

\begin{tabular}{|c|c|}
\hline Standard concentration $(\boldsymbol{\mu g} / \mathbf{m l})$ & DPPH scavenging activity $(\boldsymbol{\%})$ \\
\hline 0 & 0 \\
\hline 5 & 11.78 \\
\hline 10 & 17.49 \\
\hline 15 & 54.86 \\
\hline 20 & 70.49 \\
\hline 25 & 77.41 \\
\hline 30 & 80.65 \\
\hline 35 & 87.53 \\
\hline 40 & 92.48 \\
\hline
\end{tabular}

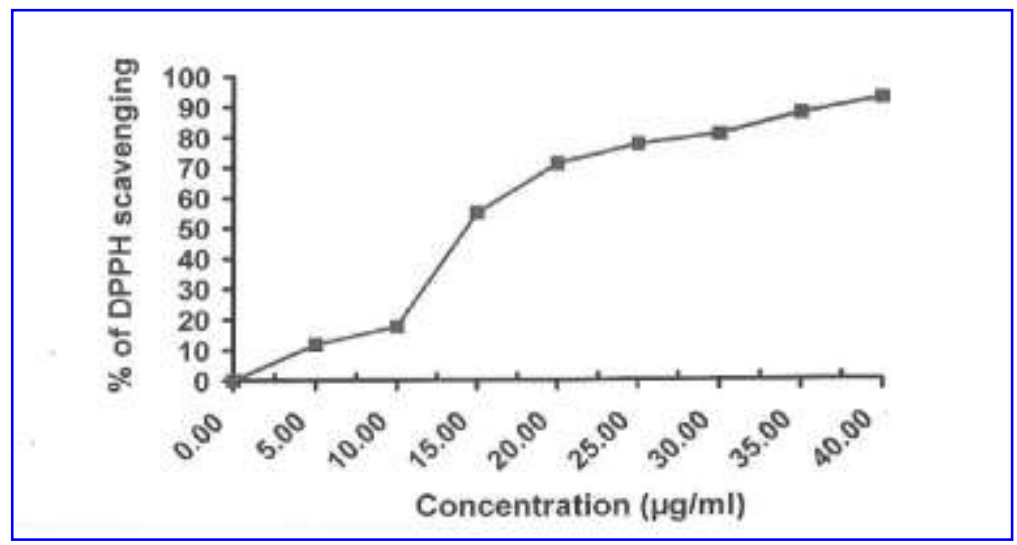

Fig. (5). DPPH scavenging activity of different concentrations of Ascorbic acid as a reference standard. 
It was obvious from Table (7) and Figures $(6 \quad \& \quad 7)$ that the scavenging activity of both extracts from $P$. peruvianae and $H$. thebaica on $\mathrm{DPPH}^{\circ}$ radicals increased with concentration, when : IC50 of $P$. peruvianae extract $=1322 \mu \mathrm{g} / \mathrm{ml}$; IC50 of $H$. thebaica extract $=771 \mu \mathrm{g} / \mathrm{ml}$.

Table (7): DPPH scavenging activity of different concentrations of Physalis peruvianae and Hyphaene thebaica

\begin{tabular}{|c|c|c|}
\hline $\begin{array}{c}\text { Sample concentration } \\
(\boldsymbol{\mu g} / \mathbf{m l})\end{array}$ & $\begin{array}{l}\text { DPPH scavenging activity } \\
(\%) \text { of physalis peruvianae }\end{array}$ & $\begin{array}{l}\text { DPPH scavenging activity (\%) } \\
\text { of Hyphaene thebaica }\end{array}$ \\
\hline 0 & 0 & 0 \\
\hline 50 & 5.67 & 10.42 \\
\hline 100 & 16.00 & 20.67 \\
\hline 200 & 20.58 & 28.50 \\
\hline 400 & 26.58 & 43.50 \\
\hline 800 & 34.92 & 50.50 \\
\hline 1600 & 58.00 & 75.08 \\
\hline 5200 & 75.25 & 85.08 \\
\hline
\end{tabular}

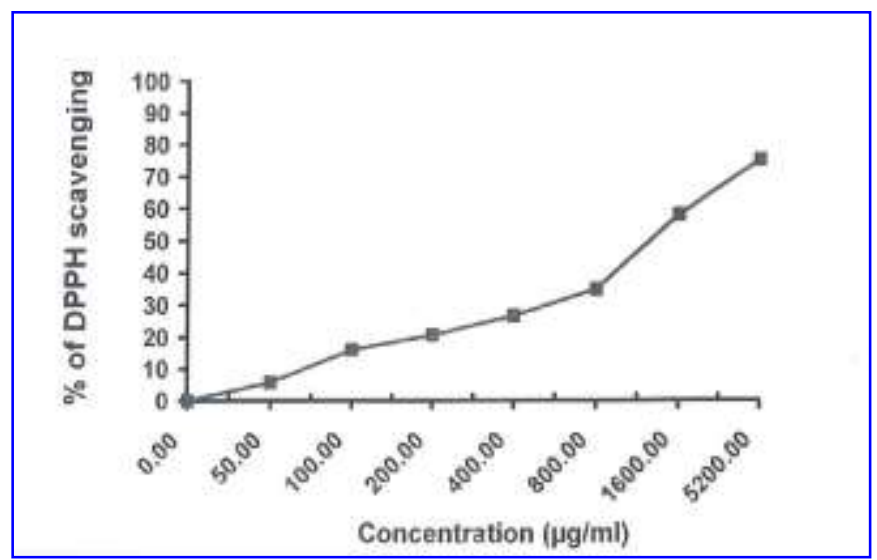

Fig. (6). DPPH scavenging activity of different concentrations of ethanol extract of Physalis peruvianae

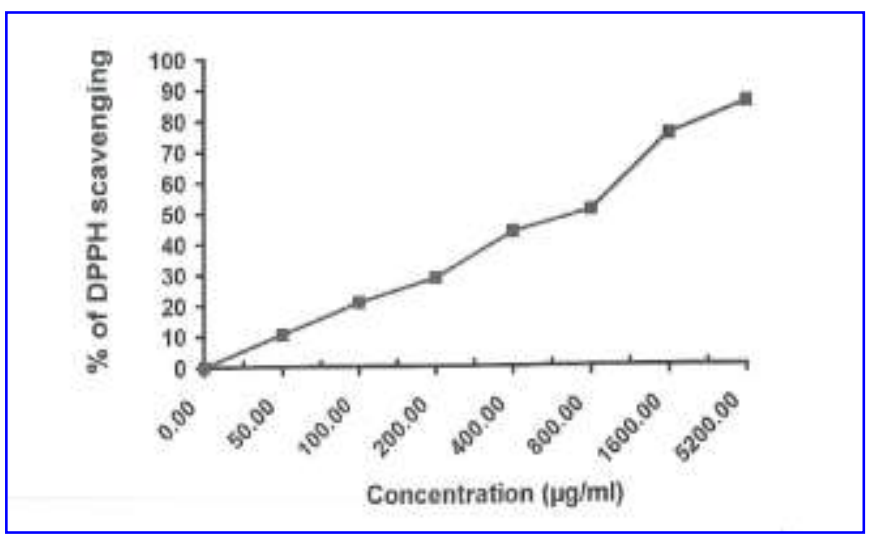

Fig. (7). DPPH scavenging activity of different concentrations of water extract of Hyphaene thebaica 
Sarah Mokhtar Abd-ELmageed et al.

\section{DISCUSSION}

The market of health and herbal neutraceuticals are addressing their attention to rich plants sources offering functional efficacy (Dua et al., 2013). The present results with Ethanol (70\%) extract of Physalis peruvianae justified that it displays a broad antibacterial spectra and all pathogens were susceptible to it at different concentrations, except Salmonella entrica at 10 and $30 \%$ concentrations and Proteus mirabilis at $10 \%$ concentration. On the other hand, the gram-negative pathogens were sensitive to Ethanol (70\%) extract ranging from 8 to 27 $\mathrm{mm}$ inhibition zones and the most affected one was Escherichia coli at 50\% concentration with the highest mean value (19.00), while the gram-positive pathogens showed its sensitivity to Ethanol $(70 \%)$ extract ranging from 10 to $23 \mathrm{~mm}$ inhibition zones and the most affected one was Staphylococcus aureus at 50\% concentration with mean value (17.67). This was agreed with the results of Çakir et al. (2014) who reported that Ethanol extract inhibited both gram-positive and gram-negative bacteria growth but there was more inhibition on gram-positive strains and Staphylococcus aureus was the most susceptible pathogen. Göztok and Zengin (2013) reported that the most susceptible gram-negative pathogens were proteus vulgaris followed by Escherichia coli and the most resistant pathogens were Pseudomonas aeruginosa and Staphylococcus aureus.

Using water extract of Hyphaene thebaica demonstrated that all pathogens were sensitive and Staphylococcus aureus was the most sensitive strain to water extract by having maximum mean value (20.33) followed by Escherichia coli, Bacillus cereus, Bacillus licheniformis, Salmonella typhimurium, Shigella dysenteriae, Proteus mirabilis and Salmonella entrica with mean values $(16.00,14.67,12.33,9.00,8.33$, $5.67,5.33)$, respectively, and there was significant difference between different concentrations $(10,30,50 \%)$ with $p$ value (0.009). This result was in agreement with that of Auwal et al. (2013) who reported that aqueous extract of Hyphaene thebaica exhibited activity on both grampositive and gram-negative pathogens such as Staphylococcu saureus, Streptococcus pyogenes, Salmonella typhi, E. coli and Shigella dysenteriae and the effect of this extract on both Gram positive and negative bacteria indicated a broad spectrum antibacterial activity. Ramadan et al. (2015) and Gautam et al. (2015) reported that ethanol extract was better than hexane extract because it has higher total phenolics content and total flavonoid compounds than does hexane extract and there is a relationship between phenolic and flavonoid contents and antibacterial and antioxidant activity. Also, using ethanol as extraction solvent was better than methnol because it is less toxic than methanol, being generally recognized as a safe solvent being more suitable for further application of golden berry extract in food (Kumari et al., 2017; Codevilla et al. 2018).

Hassan et al.(2018) reported that aqueous extract of Doum fruit has greatly antibacterial and antioxidant activities because of its luxurious amounts of water soluble phenolic contents. The present results of the comparison between each extract and synthetic antibiotic (Ciprofloxacin) revealed that Ethanol (70\%) extract of Physalis peruvianae had antibacterial activity better than synthetic antibiotic for Staphylococcus aureus, and it has the same effect for Escherichia coli. Water extract of Hyphaene thebaica had antibacterial activity better than synthetic antibiotic for Staphylococcus aureus, and it has nearly effect for Escherichia coli. This was in agreement with Ömer et al. (2017) who found that ethanolic extract of Physalis peruvianae fruit was more effective than ampicillin and cephazolin against $S$. aureus. 


\section{Antibacterial and antioxidant activities of Physalis peruviana and Hyphaene thebaica extracts}

Auwal et al. (2013) reported that aqueous extract of Hyphaene thebaica had nearly effect to tetracycline. The MIC index or (MBC/MIC ratio) was calculated for each of the investigated extracts and Rakholiya et al. (2013) and karou et al. (2005) reported that if the ratio is greater than 1 , it is considered as microbiostatic, while with ratio equal or smaller than 1 it is considered as microbiocidal. The present results indicated that ethanolic extract of physalis peruvianae has bacteriocidal effect on three pathogenic strains (E.coli, Bacillus cereus and Staphylococcus aureus) and bacteriostatic effect on the other pathogens. Water extract of Hyphaene thebaica has bacteriocidal effect on three pathogenic strains (E. coli, Salmonella typhimurium and Staphylococcus aureus) and bacteriostatic effect on the other pathogens. Abootalebian et al. (2016) reported that there is strong correlation and positive relationship between polyphenols concentration and antimicrobial and antioxidant activities in plant extracts.

In the current work, the ethanolic extract of Physalis peruvianae and water extract of Hyphaene thebaica have significant antioxidant activity (scavenging activity against DPPH radicals) in comparison with standard antioxidant (ascorbic acid). Ramadan et al. (2015) reported that ethanolic extract of physalis peruvianae has higher radical scavenging activity than hexan extract. DO et al. (2014) and Codevilla et al. (2018) reported that the antioxidant capacity of Physalis peruvianae fruit extract obtained with ethanol was higher than methanol. Chang et al. (2009) found that when concentration of extract increased, the DPPH radical scavenging activity increased.

El-Beltagi et al. (2018) recorded that doum fruit aqueous extract contain high amount of flavonoids, phenols and it was used as antioxidant and antibacterial material which can alleviate the adverse effects of oxidative stress and prevent diseases caused by pathogenic bacteria and indicated that doum fruit extracts are highly effective free radical scavengers. Doum fruit extract possesses significant antioxidant and antimicrobial activities (Mohammed et al 2018). Laith et al. (2018) found that antioxidant activity of doum fruit extracts increased by increasing the concentrations of its extracts.

In conclusion, side effects resulted from using synthetic antibiotics and chemical preservatives can be avoided by replacing them by natural plant extract as ethanolic extract of Physalis peruvianae and water extract of Hyphaene thebaica. So, further investigations on large scale are recommended.

\section{REFERENCES}

Aboaba, O.O.; Smith, S.I. and Olude, F.O.(2006). Antibacterial effect of edible plant extract on Escherichia coli O 157:H7. Pak. J. Nutri. 5: 325-327.

Adaya, A.L.; Bdliya, H.; Bitrus, H.; Fanjaji, M.; Eaton, D., et al. (1977). Hidden harvest project. Research series, Complied by International institute for environmental and Development and National Nutrition Certification Program, 3: 14-27.

Auwal, M.S. ; Mairiga, I.A.; Shuaibu, A.; Ibrahim, A.; Gulani, I.A.; Wampana, B.; Lateefat, G.I.; Lawan, F.A.; Sanda, K.A.; Thaluvwa, A.B.; Njobdi, A.N. and Yagana, K.Z. (2013). Preliminary phytochemical and in vitro antibacterial evaluation of the crude pericarp extract of Hyphaene thebaica (doumpalm) J. Medicinal Plant and Herbal Therapy Res., 1:1-7.

Arben, H.; Fatmir, F.; Arben, M.; Kemajl, $\mathrm{K}$; Imer, $\mathrm{H}$. and Ibrahim, R. (2018). In vitro antibacterial properties of ethanol extract from 


\section{Sarah Mokhtar Abd-ELmageed et al.}

Salvia officinalis (L.) plant growing wild in Kosovo. Biomed. J. Sci. \& Tech. Res., 2(3):1-3.

Idrees, B.S.M. and Mohammed, S.M. (2015). Physiochemical Characteristics of Seeds of Hyphaene thebaica (L.) Mart. J. Nat. Resour. \& Environ., Stu., 3.2(6): 9-15.

Botlon, F.J.; Coates, D. and Hutchinson, D.N. (1984). Coated from Oxoid Manual edition 9 (2006) by Oxoid Limited, England. J. Appl. Bact., 56: 151-157.

Cedeño, M. and Montenegro, D. (2004). Plan exportador, logístico y comercialización de Uchuva al mercado de Estados Unidospara FRUTEXPO SCI Ltda. Facultad de Ingeniería, vol. Ingeniero Industrial. : Bogotá Pontificia Universidad Javeriana.

Chang, J.C.; Lin, C.C.;Wu, S.J.;Lin, D.L.; Wang, S.S.; Miaw, C.L. and Ng, L.T. (2009). Antioxidative and Hepatoprotective Effects of Physalis peruviana Extract against Acetaminophen-Induced Liver Injury in Rats. Pharmaceutical Biol., Vol. 46, Nos. 10-11, pp. 724-731.

Cristiane, F.C.; Bruna, T.; Amanda, L.G.; Daniele, R.N.; Juliano, S.B.; Cristiane, B.S.; Clarice, M.B.R.; Leila, Q.Z. and Cristiano, R.M.(2018). Cytotoxicity and antioxidant activity of golden berry extracts obtained with high intensity ultrasound. Food Technology, vol.48,n.2: 1-5

Quy, D.D.; Artik, E.A.; Phuong, L.T.; Lien, H.H.; Felycia, E.S.; Suryadi, I. and Yi-Hsu, J. (2014). Effect of extraction solvent on total phenol content, total flavonoid content, and antioxidant activity of Limnophila aromatica. J. Food and Drug Analysis, 22:296-302.

Dosumu, O.O.; Nwosu, F.O. and Nwajo, C.J. (2006). Photochemical screening and antimicrobial studies of extracts of Hyphaene thebaica (L) Mart Palmae. Inter. J. Tropical Med., 1: 186-189.

Doughari, J. H. and Manzara, S. (2008). In vitro antibacterial activity of crude leaf extracts of Mangiferaindica Linn. Afr. J. Microbiol. Res., vol.(2):67-72.

Dua, A.; Garg, G. and Mahajan, R. (2013). Polyphenols, flavonoids and antimicrobial properties of methanolic extract of fennel (Foeniculum vulgar Miller). Eur. J. Exper. Biol.,3: 203-208.

Fabiola, K.; Creisiele, L.P.; Neviton, R.S.; Diogenes, A.G.C.; Elso, V.N. and Benedito, P.D.F. (2002). Screening of some plants used in the Brazilian folk medicine of the treatment of infectious diseases. Meninstoswaldo Cruz, 97:10271031.

Ferda, G. and Fikriye, Z. (2013). The antimicrobial activity of Physalis peruviana L Bitlis Eren Univ. J. Sci. \&Technol., 3:15-17.

Ghena, M.M. and Nahla, S.Z. (2018). Comparison between the chemical and antioxidant content of the Egyptian and Saudi doum fruit . Int. J. Pharm. Res. Allied Sci., 7(1):87-92.

Harvard Graphics packages Version 4 (1998).Used for representing the results graphically.

Hossam, S.E.; Heba, I.M.; Hany, N.Y. and Eman, M.F. (2018). Biological activities of the doum palm (Hyphaene thebaica L.) extract and its bioactive components. Antioxidants in Foods and Its Applications, vol.(3): 49-66.

Hassan, M.K.; Ali, S.M.; Abu-Almaaty, A.H. and Abbas, O.A. (2018). Effect of ethanolic extract of Hyphaene thebaica (L) seed on some haematological, biochemical and histological features of Albino Rats. J. Cytol. \& Histol., 9: 494 


\section{Antibacterial and antioxidant activities of Physalis peruviana and Hyphaene thebaica extracts}

Jaca T.P. and Kambizi, L. (2011). Antibacterial properties of some wild leafy vegetables of the Eastern Cape Province, South Africa. J. Med. Plants Res., 5(13): 2624-2628

Jayawardana, B.C.; Liyange, R.; Lalantha, N. and Iddamalgoda, S. (2015). Antioxidant and antimicrobial activity of drumstick (Moringa oliefera) leaves in herbal chicken sausage. Food Sci. \& Technol., 64: 1204-1208.

Karou, D.; Dicko, M.H.; Simpore, J. and Traore, A. S. (2005). Antioxidant and antibacterial activities of polyphenols from ethnomedicinal plants of Burkina Faso. Afr. J. Biotechnol., 4: 823-828.

Kaur, J.; Rathinam, X.; Kasi, M.; Leng, M.K.; Ayyalu, R.; Kathiresan, S. and Subramaniam, S. (2010). Preliminary investigation on the antibacterial activity of mango (Mangifera indica L: Anacardiaceae) seed kernel. Asian Pacific J. tropic Med., vol.3(9): 707-710.

Kumari, B. et al (2017). Ultrasoundassisted extraction of polyphenols from potato peels: profiling and kinetic modelling. Int.J. Food Sci. \& Technol., 52(6):1432-1439.

Lino, A. and Deogracios, O. (2006). The in-vitro antibacterial activity of Annona senegalensis, Securidaca longipendiculata and Steanotaenia araliacea- Ugandan medicinal plants. Afri. Health Sci., 6: 31-35.

Lapage, S.P.; Shelton, J.E. and Mitchell, T.G. (1970). In: Methods in microbiology, (Edited by Norris, J. R. and Ribbons, D.W.), 116 (3A), Academic press, London.

Lamiaa A. Gharb, LaithZ.Fadhel (2018). Antioxidant Activity of Two Different Extracts From Doum (Hyphaene thebaica) Fruits. J.
Pharm. and Biolog. Sci., vol.13: 30-33.

Manal, M. Ramadan, Ahmed H. ElGhorab and Kadry Z. Ghanem (2015). Volatile compounds, antioxidants, and anticancer activities of Cape gooseberry fruit (Physalis peruviana L.): an in-vitro study.The Arab Society for Medical Res., 10:56-64.

Mehrdad, A.; Javad, K.; Mahdi, K.; Farhad, A. and Mahnaz, A. (2016) . Comparison of total phenolic and antioxidant activity of different Mentha spicata and M. longifolia accessions. Annals Agric. Sci., 61: 175-179.

Mohamed, A.A.; Khalil, A.A. and ElBeltagi, H.E.S. (2010). Antioxidant and antimicrobial properties of kaff maryam (Anastatica hierochuntica) and doum palm (Hyphaene thebaica). Grasas Y Aceites, 61 (1):67-75.

Narváez, C.; Mateus, G. and Restrepo. S. (2014). Antioxidant capacity and total phenolic content of air-dried cape gooseberry (Physalis peruviana L.). Agronomía Colombiana, 32(2): 232-237.

Nazmi, I.; Gokcen, Y.H.; Esref, I. and Vildan, U. (2014). Effect of different drying methods on drying characteristics, colour, total phenolic content and antioxidant capacity of Golden berry (Physalis peruviana L.). Inter. J. Food Sci. and Technol., 49: 9-17.

Nurmahani, M. M., Azizah, O. O., Ghazali, F. M. and Mohd, S. P.D. (2012). Antibacterial property of Hylocereus polyrhizus and Hylocereus undantus peel extracts. Int. Food Res. J., 19: 77-84.

Ömer, E.; Melek, Ç.A.; Zehra, C.; Ülkü, K.; Kürşat, K. (2017). Antioxidant, Antimicrobial activities and phenolic and chemical contents of Physalis peruviana L. from 
Sarah Mokhtar Abd-ELmageed et al.

Trabzon, Turkey. Ind. J. Pharm. Educ. and Res., vol.51:.213-216.

Özgür, C.; Murat, P.; Elif, C.;Bilgin, C. and Kerem, F. (2014). Evaluation of biological activities of Physalis peruviana ethanol extracts and expression of $\mathrm{Bcl}-2$ genes in HeLa cells. Food Sci. and Technol., 34(2): 422-430.

Reda A.A. (2016). Characteristics of aqueous doum fruit extract and its utilization in some novel products. Annals of Agric. Sci., 61(1): 2533.

Rakholiya, K.; Kaneria, M.; Desai. D. and Chanda, S. (2013). Antimicrobial activity of decoction extracts of residual parts (seed and peels) of Mangifera indica L. Var. Kesar against pathogen and food spoilage microorganism. Sci. Technol. and Educ., vol.2:850-856.

Shariff, Z.U. (2001). Modern herbal therapy for common ailments. Nature Pharmacy Series Vol.1, Spectrum Books Ltd., Ibadan, Nigeria in Association with Safari Books (Export) Ltd. UK, pp. 9-84.
Shreesh, K. G.; Deepa, H.D. and Pawan, K. (2015). Preliminary studies on the bioactive phytochemicals in extract of Cape gooseberry (Physalis peruviana L.) fruits and their Products. J. Pharmacognosy and Phytochem., 3(5): 93-95.

Sathyadevi, M.S.S (2015). Extraction, isolation and characterization of bioactive flavonoids from the fruits of physalis peruviana linn extract. Asian J. Pharm. Clin. Res., 8(1): 152-157.

Tammu, J. and Ramana, K.V. (2015). Pharmacological review on Physalis species: A potential herbal cure-all. World J. Pharm. Res., 4 (2):247-256.

Washigton, J.A.; Warren, E. and Karlson, A.G. (1972). Stability of barium sulfate turbidity standards. Appl. Microbiol., 24: 1013.

Yen, G.C. and Duh, P.D. (1994). Scavenging effect of methanolic extracts of peanut hulls on free radical and active oxygen species. J. Agric. Food Chem.,42:629-632.

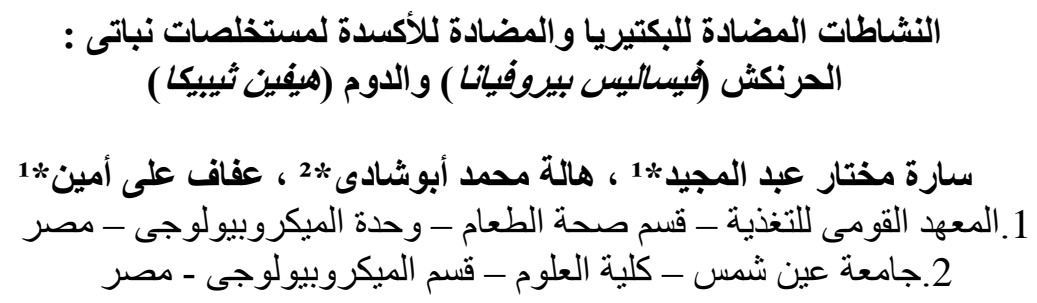

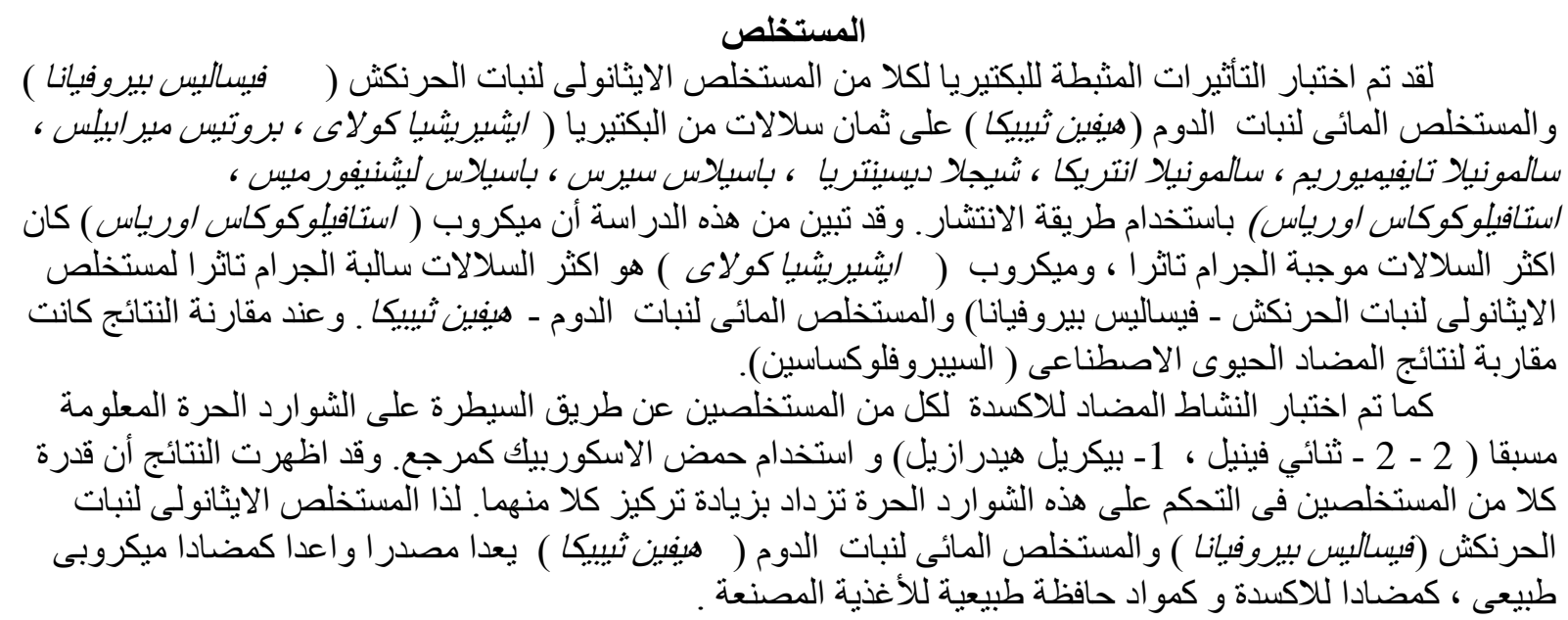

